\author{
돼지 생체에서 부분육 형질의 추정 \\ 도 창 희 \\ 경남첨단양돈연구소
}

\title{
Estimation of Carcass Cut Traits in Live Pigs
}

\author{
C. H. Do
}

Gyungnam Swine Research Institute

\begin{abstract}
Means measuring carcass cut traits in live pigs is needed to genetically improve the production of favorite cuts in swine. The data of body measurements as well as carcass traits were collected from 432 heads of 4 crossbred lines. Weights of most parts and percentages of belly and boston in carcass were significantly influenced by days to slaughter. Most of off test body measurements show higher correlations with carcass cut traits than body measurements of on test and market do. The multiple regression equations for estimation of carcass cut traits by off test body measurements have higher accuracy than by body measurements of on test and market. The coefficients of determination in estimation of polynomial regression with off test body measurements after adjustments of carcass cut traits for days to market were ranged 0.59 to 0.68 and 0.33 to 0.43 in weights and percentages of carcass cuts, respectively. Development of an excellent Korean type seed stock for favorite cuts can be expected, if the estimation of carcass cut traits for live animals is implemented in swine genetic improvement program.
\end{abstract}

(Key words : Carcass cut traits, Estimation, Accuracy, Body measurements)

\section{I. 서 론}

삼겹살과 목심은 생고기 구이의 식문화를 갖고 있는 국내의 소비자들이 특별히 선호하 는 부위이다. 삼겹살은 국내 가격이 높게 형 성되어 생산농가들의 삼겹살과 목심 생산에 대한 관심이 높은데도 불구하고 선호부위에 대한 종돈의 개량은 이루어지지 않고 있다. 비육농가는 원하지 않더라도 미국 및 유럽의 개량방법에 의해 등심이나 등지방, 일당증체 량 형질에 대해 개량된 돼지를 사육할 수밖 에 없다. 결과적으로 종돈의 개량이 소비시
장의 추세를 반영하지 못하고 있어, 선호부 위의 가격은 오르고 비선호 부위의 재고는 누적된다. 이로 인해 돈가는 떨어지고 농가 에 손실로 되돌아오고 있다. 따라서 선호부 위의 생산량을 제고시키는 돼지의 개량방법 이 절실히 요구되고 있다. 본 연구에서는 부 분육 형질들에 대하여 산업적인 관점으로 정 의하고 이 형질들에 관련된 요인을 분석하고 삼겹살과 목살 등의 국내 선호부위의 생산량 을 제고할 수 있는 개량방법을 개발하기 위 하여 연구를 수행하였다.

Corresponding author : C. H. Do, Gyungnam Swine Research Institute Sancheong Gyungnam 666-962 Korea Tel : 82-55-970-7475, E-mail : ivando@gsnd.net 


\section{ㅍ. 재료 및 방법}

공시가축은 $\mathrm{F} 1 \mathrm{DB}$ (Duroc×Berkshire), 3원교 잡 $\mathrm{DLY}[\mathrm{D} \times($ Landrace $\times$ Yorkshire $)], \mathrm{BLY}$ 와 4원 교잡 $\mathrm{DBLY}$ 432두로 검정개시(70일령 전후) 시 체측정치 조사, 검정종료시(150일령 전후) 체측정치 조사, 출하시(175일령 전후) 체측정 치를 조사하였다.

생체 조사는 축산법 종돈 검정요령을 근거 로 검정 개시, 종료, 출하시 측정치를 조사하 였다. 등지방의 측정은 A모드(Piglog 105)를 이용하여 측정하였다. $\mathrm{A}$ 모드에서는 어깨(제4 늑골, back fat 1 or bf1), 등(제14늑골, back fat 2 or bf2), 허리(최후요추, back fat 3 or bf3) 부분을 포함하는 세 부위의 등지방 두 께를 측정한다. 체장(bl: body length)은 양귀 사이의 후두부로부터 미근까지 길이, 체고 (bh: body height)는 앞다리의 바닥부터 어깨 가지 높이, 체폭(bw: body width)은 앞다리 뒤쪽 겨드랑이 사이의 폭을 측정하였다.

도체 조사를 위하여 출하 6시간 전부터 절 식을 실시하고, 도축장으로 이송하였으며, 3 4시간 계류 후 도축하였으며, 도축 후 24시 간 동안 예냉실 $\left(-3{ }^{\circ} \mathrm{C}\right)$ 에 보관한 후 냉도체(3 ${ }^{\circ} \mathrm{C}$ ) 상태에서 부분육 형질을 조사하였다. 체 중 $(\mathrm{kg})$ 은 도축 후 예냉실에 입고되기 전 자 동중량 측정기로 온도체 중량을 측정하였고, 등지방 두께 $(\mathrm{mm})$ 는 좌반도체 $10 \sim 11$ 번째 늑 골사이 및 최종 늑골 바로 위쪽을 척추면과 수직되게 측정(back fat 10 or bf10)하였다. 탕 박된 도체의 목심, 등심, 삼겹부위의 부분육 수율은 유통업자들이 시중에 유통하는 형태 로 절단하여 외피와 과도한 지방을 제거한 상태로 무게를 측정하였다.

분산분석을 통하여 생체중, 도체중 등 부 분육 형질에 대한 외부요인의 효과를 추정하 였다. 사용된 모형은 다음과 같다.

$y_{i j k}=$ farm $_{i}+$ breed $_{j}+$ sex $_{k}+$ age $+e_{i j l}$
식에서 $y_{i j k}$ 는 수집되어 분석할 형질들의 자료이고, 농장과 품종, 성별이 포함되었으 며, 측정일령은 공변량으로 포함되었고, $e_{i j k}$ 는 오차 또는 잔여효과이다.

체측치로 부분육의 중량과 수율을 추정하 기 위해서 다중회귀모형으로 분석하였고 최 적의 회귀식을 찾기 위하여 3차 다항회귀모 형을 이용하여, 추정된 모수별로 유의성을 검정하여 $\mathrm{t}$ 확률이 높은 것부터 하나의 모수 씩 삭제하여 남아있는 모수가 모두 유의성 검정에 통과할 때까지 지속하였다.

\section{II. 결과 및 고찰}

삼겹살부위는 돼지의 복부(belly family)에 속한다. 복부는 도체로부터 등심, 어깨, 다리 와 등지방을 제거한 후 만들어지며 평갈비 (spare rib)와 가죽이 부착되어 있다. 삼겹살 부위는 일반적으로 직사각형 모양으로 정육 된다. 삼겹살은 외피를 포함하거나 제거한 형태로 유통된다. 국내에서는 정육 작업이 삼겹살 생산위주로 이루어지므로 늑골이 초 기 제거되어 등심에 늑간 근육을 붙여놓거나 제거하여 잡육화 하는 형태로 작업되고 있 다. 미국의 경우 갈비는 $10 \sim 11$ 개로 이루어 지지만 삼겹살 생산을 중심으로 작업하는 국 내의 경우는 5 번 늑골까지를 갈비로 6 번 늑 골부터 7 10개의 갈비가 삼겹살 부위에 포 함된다. 등심 부핵과 부핵 지방도 삼겹살에 포함된다(흉추 5-6부터 요추 마지막).

Table 1은 부분육에 대한 중량과 수율에 대한 통계자료이다. 432 두 중 모든 형질의 자료를 포함한 383 두의 생체중의 평균은 $112.1 \mathrm{~kg}$ 이었고 도체중은 $85.1 \mathrm{~kg}$ 이었으므로 평균 도체율은 $75.9 \%$ 이었다. 수율은 각 개체 의 도체중으로부터 산출되었다. 전지, 후지 안심의 평균중량은 각각 $8.5,15.3,0.9 \mathrm{~kg}$ 이 었다. 삼겹살의 중량은 $10 \mathrm{~kg}$ 내외에서 빈도 가 가장 높았고, 삼겹살 수율은 $12 \%$ 정도에 
Table 1. Statistics of carcass cut traits

\begin{tabular}{|c|c|c|c|c|c|c|c|c|c|}
\hline & & \multicolumn{2}{|c|}{ Belly } & \multicolumn{2}{|c|}{ Boston } & \multicolumn{2}{|c|}{ Ribs } & \multicolumn{2}{|c|}{ Loin } \\
\hline & & Weight & $\%$ & Weight & $\%$ & Weight & $\%$ & Weight & $\%$ \\
\hline Mean & & 10.3 & 12.1 & 4.2 & 5.0 & 3.9 & 4.6 & 6.5 & 7.6 \\
\hline SD & & 1.1 & 1.0 & 0.5 & 0.5 & 0.5 & 0.4 & 0.8 & 0.8 \\
\hline \multirow{11}{*}{ Percentile } & 100 & 15.18 & 19.27 & 5.86 & 7.25 & 4.92 & 6.23 & 9.20 & 10.88 \\
\hline & 99 & 13.26 & 15.61 & 5.58 & 6.55 & 4.80 & 6.12 & 8.38 & 9.95 \\
\hline & 95 & 12.10 & 14.43 & 5.08 & 6.03 & 4.56 & 5.56 & 7.86 & 9.43 \\
\hline & 90 & 11.62 & 13.10 & 4.88 & 5.80 & 4.46 & 5.36 & 7.54 & 8.98 \\
\hline & 75 & 11.02 & 12.54 & 4.46 & 5.37 & 4.20 & 5.03 & 7.02 & 8.43 \\
\hline & 50 & 10.28 & 12.02 & 4.20 & 4.83 & 3.88 & 4.49 & 6.44 & 7.38 \\
\hline & 25 & 9.62 & 11.47 & 3.88 & 4.44 & 3.62 & 4.14 & 5.96 & 6.78 \\
\hline & 10 & 8.96 & 11.03 & 3.66 & 4.17 & 3.40 & 3.87 & 5.48 & 6.31 \\
\hline & 5 & 8.50 & 10.84 & 3.50 & 4.00 & 3.24 & 3.69 & 5.20 & 5.98 \\
\hline & 1 & 7.66 & 10.52 & 3.24 & 3.64 & 2.90 & 3.33 & 4.46 & 5.32 \\
\hline & 0 & 6.60 & 8.22 & 3.12 & 3.61 & 2.78 & 3.25 & 4.42 & 5.01 \\
\hline
\end{tabular}

Table 2. Analysis of variance of live weight, carcass weight and carcass cut traits

\begin{tabular}{|c|c|c|c|c|c|c|c|c|c|c|}
\hline \multirow{2}{*}{ Source } & \multirow{2}{*}{ df } & \multicolumn{9}{|c|}{ Weight } \\
\hline & & Lw & $\mathrm{Cw}$ & Belly & Boston & Ribs & Picnic & Ham & Loin & Tloin \\
\hline Farm & 3 & $276.6 *$ & 57.5 & 1.04 & 0.33 & $0.92 * *$ & $1.72 *$ & $5.46 *$ & $1.65 *$ & $0.10 * *$ \\
\hline Breed & 2 & 67.7 & 95.2 & 1.29 & $1.36 * *$ & 0.44 & 0.52 & $26.81 * *$ & $4.12 * *$ & 0.03 \\
\hline Sex & 2 & $266.8 *$ & 43.8 & 1.82 & 0.56 & 0.15 & 0.12 & $11.92 * *$ & $6.99 * *$ & $0.04 *$ \\
\hline Age & & 1086.2 ** & $403.8 *$ & $29.08 * *$ & $4.14 * *$ & $0.85 *$ & 7.16 ** & $10.45 *$ & $7.59 * *$ & 0.00 \\
\hline Error & 344 & 82.4 & 41.0 & 1.13 & 0.19 & 0.16 & 0.54 & 2.08 & 0.54 & 0.01 \\
\hline \multirow{2}{*}{ Source } & \multicolumn{10}{|c|}{ Percentage } \\
\hline & & Belly & \multicolumn{2}{|c|}{ Boston } & Ribs & Picnic & Ham & \multicolumn{2}{|c|}{ Loin } & Tloin \\
\hline Farm & 3 & $2.42 *$ & \multicolumn{2}{|c|}{$1.13 * *$} & $0.92 * *$ & 0.70 & 2.05 & \multicolumn{2}{|c|}{0.70} & $0.09 * *$ \\
\hline Breed & 2 & 7.52 ** & \multicolumn{2}{|c|}{$1.49 * *$} & $0.87 * *$ & $3.29 * *$ & \multicolumn{2}{|c|}{$54.40 * *$} & $5.23 * *$ & $0.08 * *$ \\
\hline Sex & 2 & 1.84 & \multicolumn{2}{|c|}{$0.68 *$} & 0.09 & 0.78 & \multicolumn{2}{|c|}{$26.23 * *$} & 11.21 ** & $0.09 * *$ \\
\hline Age & 1 & $12.43 * *$ & \multicolumn{2}{|c|}{$1.55 * *$} & 0.00 & 0.70 & \multicolumn{2}{|c|}{0.19} & 1.74 & 0.03 \\
\hline Error & 344 & 0.81 & \multicolumn{2}{|c|}{0.17} & 0.13 & 0.37 & \multicolumn{2}{|c|}{1.79} & 0.51 & 0.01 \\
\hline
\end{tabular}

Note Lw: live weight, Cw:: carcass weight, Tloin: tender loin.

서 가장 높았다.

Table 2에 부분육의 중량과 수율에 대한 농장, 품종, 성별과 출하일령에 대한 영향을 조사하여 제시하였다. 부분육에서 품종과 성
별에 대한 효과를 조사하기 위한 분석에서 출하일령은 공변량으로 모형에 삽입 분석하 여 일령에 대한 부분육의 중량이나 수율의 보정을 대신하였다. 생체중과 도체중은 품종 
에 따라 유의적 차이가 없었다. 그러나 부분 육의 중량에 있어서는 목심, 후지 등심에서 유의적 차이가 나타났다. 성별의 효과는 생 체중 후지 등심에서 유의적인 영향을 미치는 것으로 나타났다. 그러나 출하일령은 안심을 제외하고는 체중과 부분육의 중량에 크게 영 향하는 것으로 나타났다. 부분육의 수율에 영향을 미치는 요인은 품종의 효과가 모두 유의성 있게 나타났다. 출하일령도 삼겹살과 목심의 수율에 영향하는 것으로 나타났다. 삼겹살의 중량은 품종이나 성에 따른 차이가 유의성이 없었으나 삼겹살 수율은 품종에 따 른 차이가 인정이 된다. 이는 품종에 따라 체형의 차이가 있어 수율을 개선 할 수 있는 가능성을 보여준다.

체형질을 측정하기 시작한 개시일령은 72.3 일이었고 표준편차는 3.2 일이었으며, 종
료일령의 평균 151.3일 표준편차 4.6일 그리 고 출하일령의 평균은 179.2 일 표준편차는 9.2 일이었다. 검정 개시시, 종료시 그리고 출 하시 체형과 부분육과의 상관관계를 Table 3 에 제시하였다. 출하일과 측정일간의 거리가 먼 개시일령의 체형과도 비교적 높은 상관을 갖는 것은 유의할 만한 점이며 체형과 부분 육과의 관계가 어느 정도 골고루 나타났다. 부분육의 구성에 체중도 중요한 부분을 차지 하는 것으로 나타났고 그 외의 체측형질이 더욱 정확한 예측을 가능하게 하는 요인이 된다고 볼 수 있다. 출하체중과 출하체고, 출 하체폭, 등지방 두께들이 양의 상관을 보여 주고 있다. 특히 체중을 제외한 대부분의 체 형 형질에서 종료시 체측정치가 출하시의 체 측정치보다 높은 상관을 가지는 것은 예상과 는 다른 것으로 종료시의 골격이 더욱 정확

Table 3. Correlations between body measurements and carcass cut traits

\begin{tabular}{|c|c|c|c|c|c|c|c|c|c|}
\hline & & \multicolumn{2}{|c|}{ Belly } & \multicolumn{2}{|c|}{ Boston } & \multicolumn{2}{|c|}{ Ribs } & \multicolumn{2}{|c|}{ Loin } \\
\hline & & Weight & $\%$ & Weight & $\%$ & Weight & $\%$ & Weight & $\%$ \\
\hline \multirow{4}{*}{ On test } & Weight & .38 & .18 & .19 & -.06 & .32 & .09 & .20 & -.01 \\
\hline & Body length & .33 & .16 & .14 & -.08 & .32 & .14 & .18 & -.00 \\
\hline & Body height & .36 & .19 & .11 & -.11 & .30 & .11 & .12 & -.06 \\
\hline & Body width & .37 & .21 & .16 & -.04 & .26 & .08 & .16 & -.02 \\
\hline \multirow{7}{*}{ Off test } & Weight & .66 & .44 & .31 & -.01 & .45 & .16 & .24 & -.06 \\
\hline & Body length & .40 & .23 & .24 & .01 & .26 & .03 & .30 & .10 \\
\hline & Body height & .43 & .26 & .17 & -.08 & .36 & .14 & .20 & -.02 \\
\hline & Body width & .37 & .18 & .30 & .07 & .33 & .12 & .19 & -.03 \\
\hline & Back fat 1 & .37 & .26 & -.06 & -.26 & .13 & -.05 & -.24 & -.45 \\
\hline & Back fat 2 & .37 & .27 & -.01 & -.19 & .09 & -.08 & -.21 & -.39 \\
\hline & Back fat 3 & .29 & .16 & .03 & -.18 & .06 & -.16 & -.14 & -.34 \\
\hline \multirow{7}{*}{ Market } & Weight & .76 & .37 & .40 & -.11 & .64 & .17 & .34 & -.11 \\
\hline & Body length & .33 & .13 & .28 & -.05 & .27 & .03 & .24 & .03 \\
\hline & Body height & .17 & -.03 & .30 & .12 & .18 & -.02 & .28 & .13 \\
\hline & Body width & .35 & .10 & .26 & -.02 & .19 & -.11 & .07 & -.18 \\
\hline & Back fat 1 & .24 & .11 & -.13 & -.34 & .08 & -.11 & -.30 & -.50 \\
\hline & Back fat 2 & .31 & .21 & -.17 & -.37 & .08 & -.09 & -.31 & -.51 \\
\hline & Back fat 3 & .06 & -.05 & -.12 & -.26 & .01 & -.13 & -.21 & -.33 \\
\hline \multirow{2}{*}{ Carcass } & Weight & .64 & .00 & .50 & -.18 & .62 & -.05 & .46 & -.13 \\
\hline & Back fat 10 & .22 & .05 & -.09 & -.32 & .03 & -.21 & -.16 & -.39 \\
\hline
\end{tabular}


하게 부분육의 형성에 영향한다고 사료되고, 이런 분석결과가 종료시 체측정치의 중요성 을 의미한다. 이는 종료시점인 150 일령 이후 에는 비육후기의 사료를 급여하여 육질을 개 선하고 빠른 시간에 증체시키는 사육방법을 실시하는데 따른 영향이라 추측된다.

선호부위의 경제적 가치는 비선호 부위와 비교하여 차이가 크다. 선호부위를 평가하여 유전적으로 수율을 개선하거나 양을 증대시 킬 수 있다면 우선적으로 육가공업자 그리고 농가에 경제효과는 상당할 것으로 추정된다. 돼지에서 유전적으로 $1 \mathrm{~kg}$ 증량 했을 경우 $2 \sim 3,000$ 원의 경제효과라면 삼겹살 $1 \mathrm{~kg}$ 의 증 량은 그것의 5 배 정도의 경제효과를 얻을 수 있다. Table 1에 제시된바와 같이 측정된 이 들 부분육의 중량과 수율에 충분한 변이가 존재하여 개량할 여지가 많이 있음을 알 수 있다.

올바른 예측을 위해서 우선 출하시 기준을 정하고 이 연구를 위해 수집한 부분육에 대 한 보정을 해야 한다. 출하일의 평균 179.2 일 령이었고 체중은 $112.1 \mathrm{~kg}$ 이다. 따라서 선호 부위의 측정치를 출하 기준에 적합하게 보정 을 해준 후 그 자료를 가지고 예측하기 위한 절차를 수행하여야 한다. 먼저 출하일령에 따른 부분육의 중량과 수율을 보정한 후 이 값을 가지고 검정시 체측정치들에 의해 예측 하는 방법이 합리적이라고 사료된다. 보정을 하는 방법은 여러 가지 있을 수 있지만 회귀 를 이용하는 것이 가장 간편하다. 회귀계수 계산은 절편(intercept) 없는 회귀로 체중 및 선호부위 형질을 종속변수로 출하일령을 독
립변수로 추정하여 Table 4에 제시하였다. 추 정시 회귀의 적합도를 보여주는 결정계수는 모든 형질에서 0.98 또는 0.99 를 보여주었다.

표에 제시된 체중은 출하시 체중이며 이에 대한 회귀계수는 .62317이다. 따라서 $110 \mathrm{~kg}$ 도달일령은 176.5 일이다. 다음은 회귀계수를 이용 각 부분육 및 수율에 대하여 보정하는 식이다.

$$
\left.\hat{y}_{i}=y_{i}-b_{1} \text { (출하일령 }-176.5\right) \cdots \cdots
$$

식에서 $y_{i}$ 부분육 또는 수율에 대한 실측 치이고, $\hat{y}_{i}$ 는 일령에 의해 $110 \mathrm{~kg}$ 기준으로 보정된 값이며, $b_{1}$ 은 Table 4 에 제시된 형질 별 회귀계수이다. 위의 식은 개체의 능력에 의한 변이를 그대로 유지 하면서 출하 일령 에 의한 형질 별 차이만 보정하게 된다.

Table 5는 검정개시일에 측정한 형질들을 이용하여 부분육의 중량과 수율을 추정하였 다. 회귀식의 결정계수가 비교적 낮게 나타 났다. 목심 중량에서 0.3532 로 가장 높게 나 타났다. 이러한 낮은 수치들은 출하일령과 검정개시일령과 차이의 평균이 106.9 일이나 되어 낮게 나타난다고 사료된다. 체측정 일 령의 회귀계수는 삼겹살 수율을 제외한 모든 부분육의 중량과 수율에서 고도의 유의성을 보여준다. 생후 70 일령 전후의 성장시기는 일령에 따라 체측정치의 변이가 부분육과 수 율에 밀접하게 영향한다 말할 수 있다. 그 외에 체중의 회귀계수는 삼겹살을 제외한 모 든 형질에서 유의성이 높게 나타났다.

출하시 측정치로 예측을 할 때는 출하일령 이 공변량으로 회귀식에 포함되기 때문에 앞

Table 4. Regression coefficients for adjustment of carcass cut traits based on days to 110 $\mathrm{kg}$ of live weight

\begin{tabular}{|c|c|c|c|c|c|c|c|c|c|}
\hline & \multirow{2}{*}{ Weight } & \multicolumn{2}{|c|}{ Belly } & \multicolumn{2}{|c|}{ Boston } & \multicolumn{2}{|c|}{ Ribs } & \multicolumn{2}{|c|}{ Loin } \\
\hline & & Weight & $\%$ & Weight & $\%$ & Weight & $\%$ & Weight & $\%$ \\
\hline Reg coeff $\left(b_{1}\right)$ & .62317 & .05713 & .06712 & .02342 & .02753 & .02158 & .02537 & .03611 & .04245 \\
\hline $\mathrm{R}^{2}$ & .99 & .99 & .98 & .99 & .99 & .98 & .99 & .99 & .98 \\
\hline
\end{tabular}


Table 5. Estimation of carcass cut traits by body measurements of on test

\begin{tabular}{|c|c|c|c|c|c|c|c|c|}
\hline & \multicolumn{2}{|c|}{ Belly } & \multicolumn{2}{|c|}{ Boston } & \multicolumn{2}{|c|}{ Ribs } & \multicolumn{2}{|c|}{ Loin } \\
\hline & Weight & $\%$ & Weight & $\%$ & Weight & $\%$ & Weight & $\%$ \\
\hline Intercept & 6.2205 & 9.8819 & 8.4521 & 11.1271 & 3.8332 & 5.6299 & 11.8730 & 15.6760 \\
\hline Days & $-.0582 * *$ & -.0432 & - .0922 ** & $-.0986 * *$ & $-.0310 * *$ & $-.0271 * *$ & $-.13210 * *$ & $-.1394 * *$ \\
\hline Weight & .0557 & .0206 & $.0495 * *$ & $.0394 * *$ & $.03612 * *$ & $.0277 *$ & $.0648 * *$ & $.0472 *$ \\
\hline Body length & .0250 & .0151 & .0097 & .0051 & .0050 & -.0007 & $.0334 *$ & $.0301 *$ \\
\hline Body height & $.0728 *$ & .0328 & .0096 & -.0118 & .0219 & .0045 & .0121 & -.0203 \\
\hline Body width & .1288 & .1336 & .0028 & -.0034 & .0078 & -.0010 & -.0199 & -.0361 \\
\hline $\mathrm{R}^{2}$ & .2575 & .0996 & .3532 & .2876 & .2558 & .0980 & .3168 & .2333 \\
\hline
\end{tabular}

Table 6. Estimation of carcass cut traits by body measurements at market

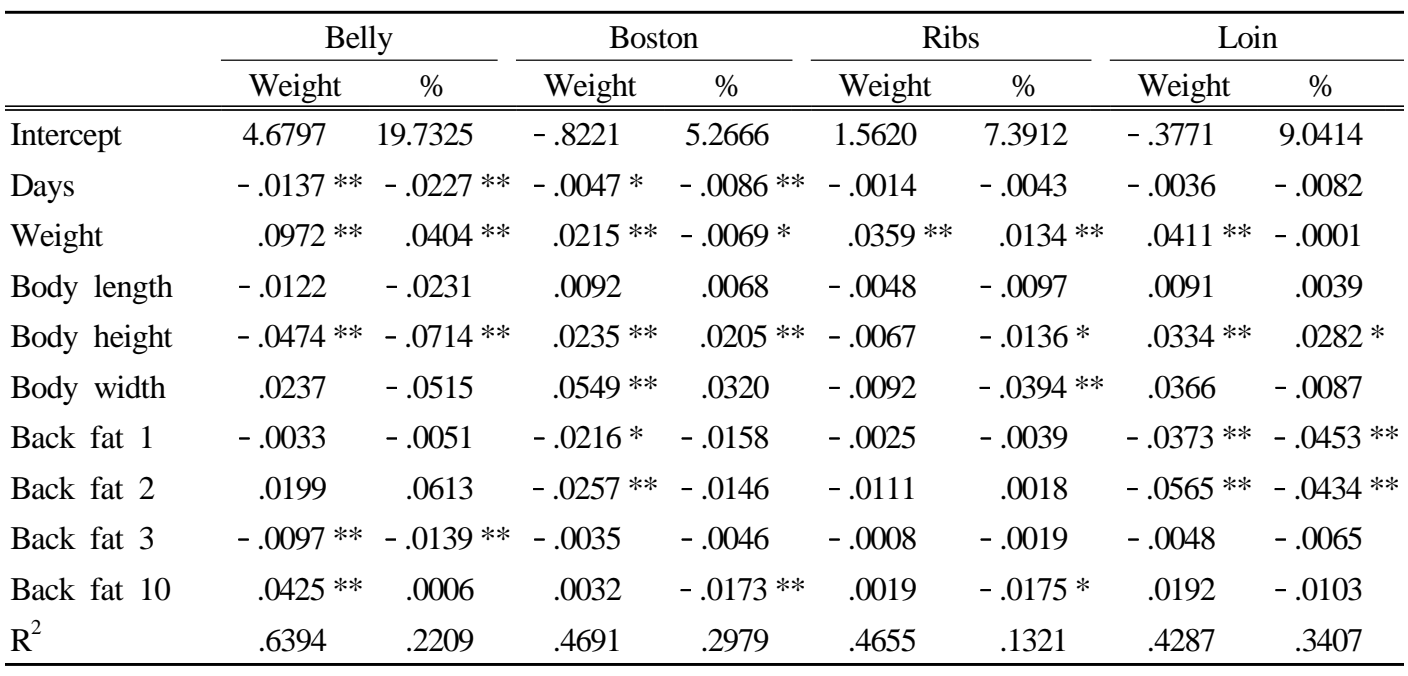

Table 7. Estimation of carcass cut traits by body measurements of off test

\begin{tabular}{|c|c|c|c|c|c|c|c|c|}
\hline & \multicolumn{2}{|c|}{ Belly } & \multicolumn{2}{|c|}{ Boston } & \multicolumn{2}{|c|}{ Ribs } & \multicolumn{2}{|c|}{ Loin } \\
\hline & Weight & $\%$ & Weight & $\%$ & Weight & $\%$ & Weight & $\%$ \\
\hline Intercept & 4.8799 & 9.6156 & 7.5629 & 10.8292 & 4.0547 & 6.5606 & 12.7972 & 17.9283 \\
\hline Days & $-.0338 * *$ & -.0139 & $-.0507 * *$ & $-.0499 * *$ & $-.0263 * *$ & $-.0221 * *$ & $-.0775 * *$ & $-.0754 * *$ \\
\hline Weight & $.0843 * *$ & $.0739 * *$ & $.0391 * *$ & $.0351 * *$ & $.0307 * *$ & $.0271 * *$ & $.0624 * *$ & $.0570 * *$ \\
\hline Body length & -.0066 & -.0245 & .0072 & .0009 & -.0005 & -.0078 & .0162 & .0072 \\
\hline Body height & .0181 & -.0010 & -.0076 & -.0193 & .0155 & .0077 & -.0134 & -.0304 \\
\hline Body width & $.0863 * *$ & .0087 & $.0450 * *$ & .0127 & .0190 & -.0137 & .0158 & -.0456 \\
\hline Back fat 1 & .0078 & .0099 & $-.0021 * *$ & $-.0248 *$ & -.0002 & .0001 & $.0443 * *$ & $-.0523 * *$ \\
\hline Back fat 2 & -.0069 & .0178 & $-.0258 * *$ & -.0188 & $-.0143 *$ & -.0069 & $.0689 * *$ & $-.0640 * *$ \\
\hline Back fat 3 & .0158 & -.0042 & -.0021 & -.0124 & -.0078 & $-.0182 * *$ & .0012 & -.0156 \\
\hline $\mathrm{R}^{2}$ & .6647 & .3884 & .6560 & .4105 & .5797 & .3056 & .6088 & .4436 \\
\hline
\end{tabular}


의 검정 개시와 종료시처럼 (1)식에 의해 출 하일령에 따른 보정을 할 필요가 없어진다. 출하시의 부분육에 대한 평가는 실질적으로 돼지 돈가 결정에 영향할 수 있어 의미를 가 지지만 실용여부는 얼마나 쉽고 정확하게 적 용할 수 있는가에 달려있다. 그러나 출하시 개체별로 조사하여 가치를 평가하는 일은 얻 어지는 실익보다 번거로움이 크기 때문에 현 재로서는 활용가치가 없다. 다만 출하 이전 의 자료로 예측하는 것과 정확도를 비교하기 위하여 회귀식을 추정하여 Table 7에 제시하 였다. Table 3의 상관분석에서도 예견이 되었 지만 출하시 체측정치를 이용한 부분육에 대 한 예측이 검정 개시일에 측정한 것보다는
정확하게 예측이 되었다.

일반적으로 돼지의 개량을 위해서 종돈장 에서 검정종료시 최종적으로 개체의 자료를 조사한다. 이러한 도축전의 측정 자료를 가 지고 도축 후 삼겹살이나 목살의 양을 예측 할 수 있다면 중요한 의미가 있다. Table 7에 검정 종료시 측정치를 이용하여 부분육의 중 량과 수율을 예측하였다. 종료일령과 출하일 령의 평균차이는 27.9일이었고 당연한 결과 이지만 검정개시시 체측정치를 이용한 예측 보다 모든 형질에서 높은 정확도를 보여주고 있고, 중량에서의 결정계수가 수율에서보다 높게 나타나고 있다. 종료시 측정일령의 회 귀계수는 개시시와 마찬가지로 삼겹살의 수

Table 8. Polynomial regression equation for estimation of carcass cut traits by body measurements of off test(at most $\mathrm{P}<.05$ for $\beta_{i}$ )

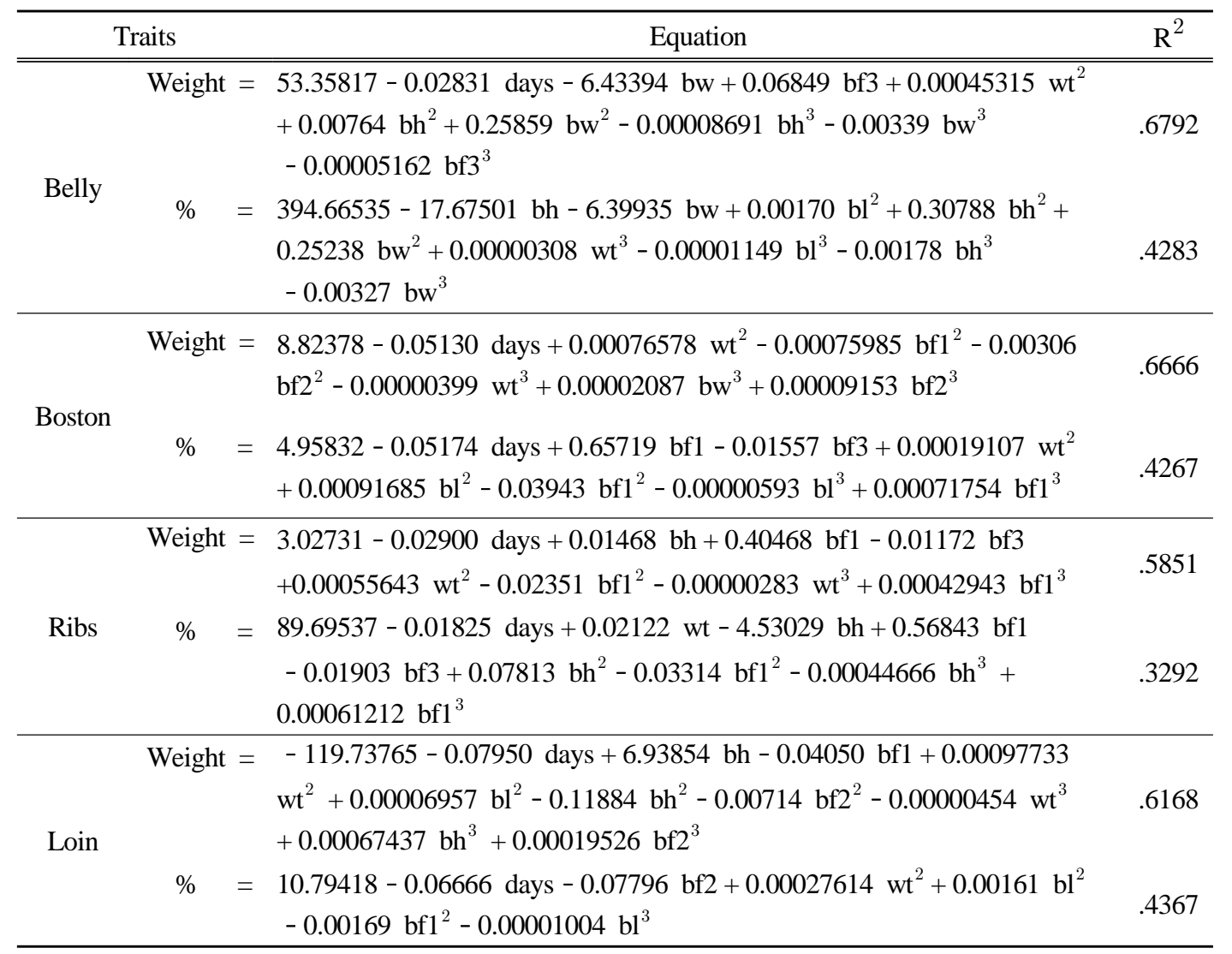

Note days: days to off test, wt: weight, bl: body length, bh: body height, bw: body width. 


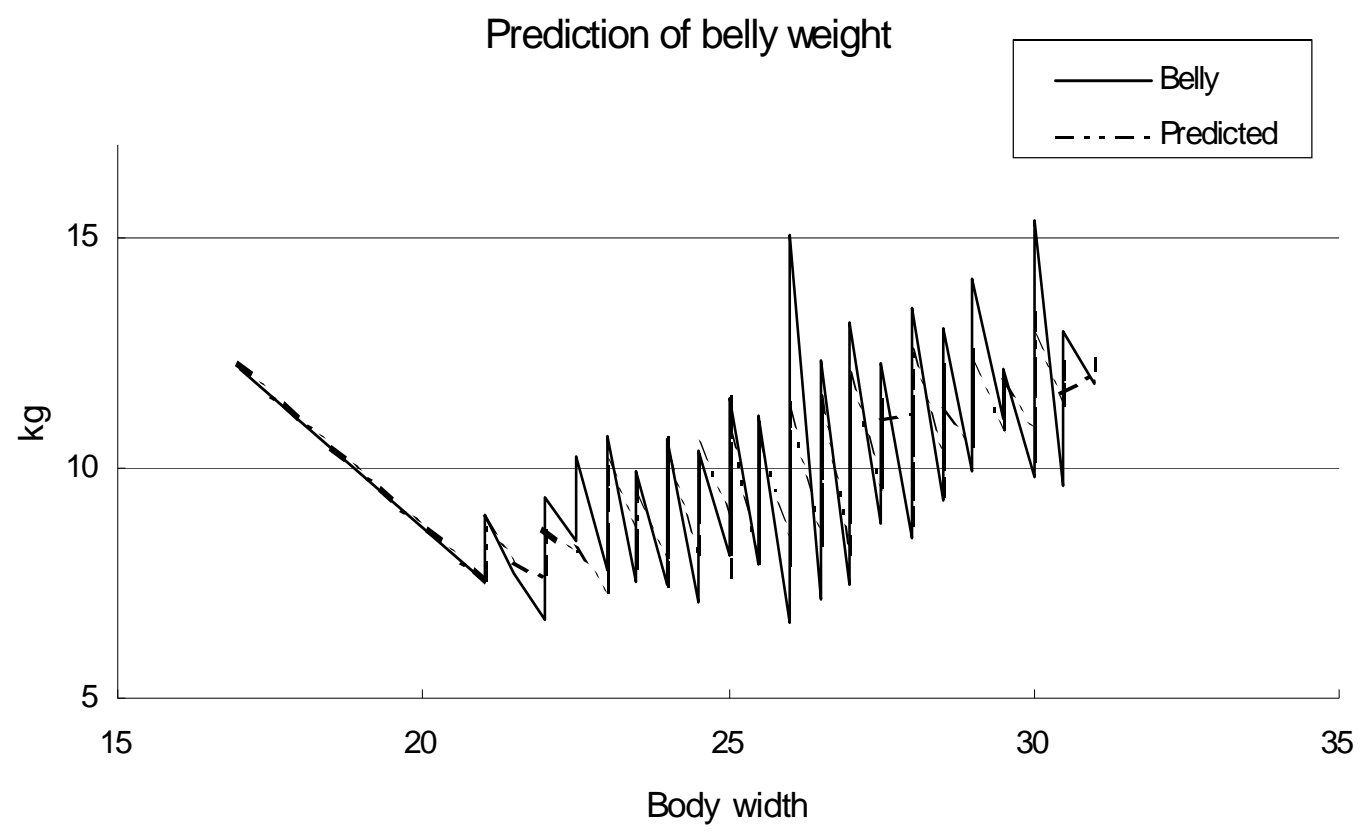

Fig. 1. Prediction of belly weight by third polynomial regression equation using off test body measurements.

율을 제외한 모든 형질에서 높은 유의성을 보여주고 있다. 체중의 회귀계수는 모든 형 질에서 고도의 유의성을 보여주고 있다. 체 형형질에서는 체폭의 회귀계수가 삼겹살과 목심에서 유의성 있게 나타났다. 정확도를 Table 6의 출하시 체측정치의 회귀식과 비교 할 때 모든 형질에서 Table 7의 종료시 체측 치 회귀식이 높게 나타났다. 이미 종료시 체 측치에 도축 후 부분육과 수율에 대한 설명 이 이미 이루어지고 약 28 일간의 비육기에는 오히려 체측정치에서 부분육에 대하여 표현 할 수 있는 부분을 가리는(disguise) 과정이라 사료된다. 이 분석결과에 따르면 종료시 체측 정치가 다른 시기의 측정치보다 의미가 높다.

Table 5, 6과 7에서 부분육의 중량과 수율 의 예측을 위한 회귀식이 1 차 다중회귀에 의 해 예측하였지만 회귀모수 추정치들의 유의성 이 없는 체측정치들이 있었다. 유의성이 없다 하여 종속변수에 대한 영향이 반드시 없다 할 수는 없지만 변수의 변환을 통하여 그 영향을
효과적으로 설명할 가능성도 있다. 따라서 독 립변수인 체측치들의 3 차까지의 모수를 회귀 식에 포함하였다. 전체 정확도를 크게 삭감하 지 않으며 유의성 있는 모수들만 식에 잔류하 게 하여 회귀예측식을 결정하였다. 회귀모수 (regression parameters)의 유의성 검정을 위해 서는 다음과 같은 귀무가설이 도입된다.

$$
H_{0}: \beta_{i}=0
$$

모수들의 추정치는 귀무가설을 유의적으로 기각하여야 하며 전체 회귀식에 대한 정확도 는 결정 계수로서 평가된다. 3 차 다항회귀모 형을 채택하여 추정된 각 모수들의 $\mathrm{t}$ 분포 확률이 큰 것부터 차례로 제거하여 모든 추 정치가 귀무가설을 유의적으로 기각할 때(at most $\mathrm{P}<.05$ ) 까지 지속하였다. Table 8에 최 종 결정된 부분육의 중량과 수율을 예측하기 위한 다항회귀 식을 제시하였다. 표에 나타 나듯이 다중회귀식으로 추정하였을 때보다 
모든 형질에서 정확도가 높아졌다. 특히 체 중은 모든 형질에서 1 차 독립변수로서는 유 의성이 낮아 삭제되었지만 2차 또는 3차 변 수로 모두 포함되었다. 이는 종료체중이 부 분육 형질의 예측에 기여하기 위해서는 변환 (transformation)이 필요한 것을 의미한다. 체 측치들의 변환이 회귀모수의 유의성을 높여 줄 뿐만 아니라 전체 식의 정확도도 높여주 고 있다.

Table 8의 삼겹살 중량을 예측하기 위한 다항회귀식을 이용한 예측치와 실제 값을 그 래프로 Fig. 1에 제시하였다. 1차식으로 포함 된 체폭을 $\mathrm{x}$ 축으로 설정하고 그린 도표이다. 표에 제시된 것처럼 결정계수의 값은 .6792 로서 예측치를 이용하여도 상관계수가 0.82 로서 개량을 위한 형질 자료로서 충분한 활 용가치가 있다고 사료된다. 체폭은 연속변수 인데 관측치들의 값이 한정되어서 그림에서 불연속변수처럼 나타나있다. 그럼에도 불구 하고 예측치가 관찰치를 따라가는 추세는 잘 보여주고 있다.

선호부위의 중량을 예측할 것이냐 수율을 예측할 것이냐 하는 문제는 종돈의 경제성과 관련이 있다. 일반적인 육종학 시각으로 보 면 중량에 대해 선발하면 다른 형질들 즉 대 부분의 산육형질 들과 높은 유전상관관계가 예상된다. 따라서 부분육 중량을 예측하고 이를 활용 육종하여 간다면 종돈의 크기가 큰 쪽으로 개량되어질 것이다. 반면에 수율 을 예측하고 이를 육종에 활용한다면 이는 돼지의 체형 구조(body structure)에 더 많은 관심을 갖는 결과가 된다. 돼지의 크기인가 체형인가도 향후 돼지의 개량방안에 새로운 안건으로 부상할 수도 있다. 두 가지 접근 방식 모두 선호 부위의 개량에 긍정적인 방 향으로 유도한다. 자료가 누적이 되면 육종 가 추정이 가능해지고 부분육의 중량과 수율 의 유전력에 있어서도 차이가 예견된다.

\section{IV. 요 약}

돼지의 부분육의 중량과 수율의 개량을 위 하여 생체에서 이를 측정할 수 있는 수단이 필요하다. 4개의 교잡 계통돈 돼지 432두에 대하여 시기별 생체 측정치와 도축자료를 조 사하였다. 생체중 및 도체중 그리고 부분육 의 중량은 도축일령에 의해 영향을 거의 모 두 받고 있지만 수율에 있어서는 삼겹살과 목심에만 유의성있게 영향하는 것으로 나타 났다. 부분육의 형질과 시기별 생체 측정치 간의 상관 조사에서 대부분의 체측정치에서 검정 종료시의 측정치가 다른 시기의 측정치 보다 상관이 높게 나타났고, 부분육 형질의 예측을 위한 회귀식에서도 검정 개시와 출하 시의 체측정치 보다 검정 종료시 체측정치를 이용하였을 때 결정계수가 모든 부분육의 형 질에서 높아 가장 정확하게 추정하였다. 부 분육 형질을 평균 출하일령으로 보정한 뒤, 검정 종료시 체측정치의 3 차 다항회귀 식에 의한 부분육 형질의 예측에서 중량과 수율의 결정계수가 각각 $0.59 \sim 0.68$ 과 $0.33 \sim 0.43$ 의 범위를 보여주어 이를 돼지의 부분육 형질의 개량을 위해 활용하면 국내 선호부위가 우수 한 한국형 종돈의 생산이 기대된다.

$$
\mathrm{V} \text {. 사 사 }
$$

본 연구는 2004년도 농림부 현장애로기술 개발 사업 연구 결과의 일부로 연구비 지원 에 감사드립니다.

\section{VI. 인 용 문 헌}

1. Barton-Gade, P. A. 1990. Pork quality in genetic improvement programmes- the Danish experience. Proc. of the National Swine Improvement Federation Annual Meeting. Des Moines, IA. 
2. Liu, Y. and Stouffer, J. R. 1995. Pork Carcass evaluation with an automated and computerized system. J. Anim. Sci. 73:29-38.

3. Schworer, D. A., Rebsamen, A. and Lorez, D. 1995. Selection of intramuscular fat in Swiss pig breeds and importance of fatty tissue qualit 2nd Dummerstorf Muscle Work- shop on Growth Meat Quality. Rostock.

4. Wood, J. D. 1985. Consequences of changes in carcass composition on meat quality. age 157 in Recent Advances in Animal Nutrition. W. Haresign and D. J. A. Cole, ed. Butterworths, London.

(접수일자 : 2007. 2. 22. / 채택일자 : 2007. 4. 20.) 